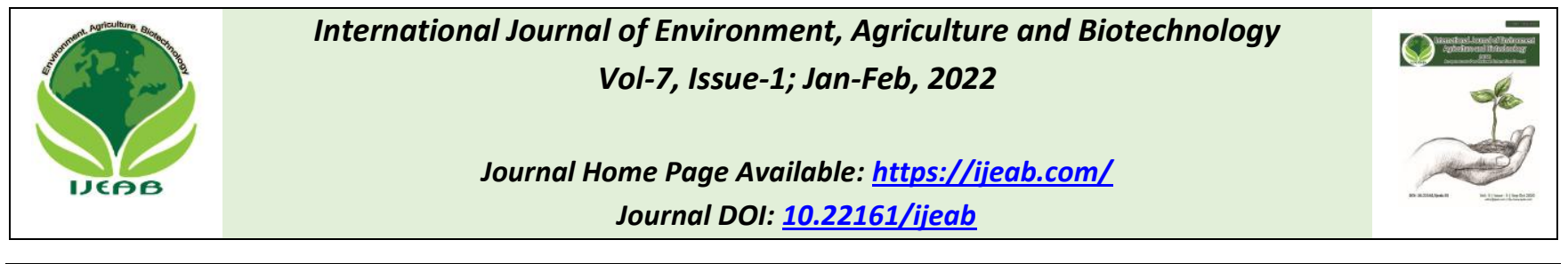

Peer Reviewed

\title{
Bioprospection, morphological and biochemical characterization and evaluation of the antimicrobial activity of the bacterial strains of chicken breeding soil (Gallus gallus domesticus) in the city of Igarapé-Açu, Pará
}

\author{
Caroline Ferreira Fernandes, Juliana Hiromi Emin Uesugi, Jonatan Carlos Cardoso da \\ Silva, Daniel dos Santos Caldas, Maria Clara Coelho Prazeres, Nilson Veloso Bezerra
}

Microbiology Applied Laboratory, University from Pará State, Brazil

Email: gebac.labmicro@gmail.com

Received: 20 Dec 2021; Received in revised form: 10 Feb 2022; Accepted: 18 Feb 2022; Available online: 26 Feb 2022

(C)2022 The Author(s). Published by Infogain Publication. This is an open access article under the CC BY license

(https://creativecommons.org/licenses/by/4.0/).

\begin{abstract}
The soil is a propitious place for the development of decomposer microrganisms, mainly fungi and bacteria. The soil colonization from those organisms occurs in places with great availability of organic matter, like the rhizosphere and animal breeding soils, like poultry farming. Among the microrganisms present in this type of soil, there are the actinomicetes, which belong to phylum of gram-positive bacteria with filamentous estructures that constitute aerial mycelia. The objective of this article was to isolate, bioprospect, characterize morfologically and biochemically and to assess the antimicrobial potential of strains of bacterias from chicken breeding in the city of Igarapé-Açu, Pará. As a result, bacterial colonies with variable features that indicate the genus Actinobacteria were found, amongst them one showed potential antibacterial against a strain of Klebsiella pneumoniae
\end{abstract}

Keywords-Actinobacteria, Gallus gallus domesticus, bacterial resistance.

\section{INTRODUCTION}

Soil is a promising place for the growth of microorganisms, especially decomposers such as bacteria and fungi (Su et al., 2020). It is estimated that for every 1 gram of soil abundant in organic matter, there are 109 to 1010 prokaryotic organisms (bacteria and archaea) (Srinivasiah, 2008; Tecon, 2017). In places of animal husbandry, such as poultry husbandry, there is a wide availability of this type of material that enriches the soil with primary and secondary macronutrients that promote the proliferation of many organisms (Menegaço, 2017).

Among the microorganisms present in soils intended for poultry farming activities, actinomycetes stand out, which belong to a phylum of gram-positive bacteria that have a filamentous organization, form structures called aerial mycelium and present regions rich in cytosine and guanine in their DNA (Oliveira, 2021; Ramos, 2015). It is important to emphasize that this phylum has a great morphological variety, which can be bacilli, coccoids, coccobacilli, in short or rudimentary hyphae forms (Barka et al., 2016; Medeiros, 2018).

In addition to actively participating in the degradation of organic matter, this group of bacteria exhibit several physiological and metabolic properties such as the production of extracellular enzymes, antitumor agents, antifungal and antibacterial substances, especially bacteria of the genus Streptomyces (Uesugi et al, 2021; Hopwood, 2007; Brito, 2015). Due to the wide variety of metabolites, this phylum has become a great source of compounds of medical importance and of great commercial value for the pharmaceutical industry, especially with regard to the 
production of antimicrobial drugs (Espinosa, 2012; Pimentel, 2016).

The actinomycetes are promising sources for the production of some of the most important classes of antibiotics, such as beta-lactams, tetracyclines, aminoglycosides, macrolides, among others (Genilloud, 2017). Its antibiotic action occurs from the synthesis of bactericidal substances from various enzymatic complexes, such as polyketide synthase (PKS's) and non-ribosomal peptide synthases (NRP's) (Quinn, 2020).

Antimicrobial Resistance (AMR) represents a serious public health problem, since medical treatment against bacterial infections has become increasingly limited, resulting in greater clinical complications for hospitalized patients, resulting in a providing number of deaths (Costa, 2017). It is estimated that around 700 thousand deaths annually are related to this problem (Angles, 2018).

One of the biggest barriers in the confrontation against AMR is the development of new technologies, considering that the number of laboratories and pharmaceutical companies that invest in the research of new antibiotics has fallen in the last decades due to low profitability. Allied to this, the production of new drugs with antimicrobial properties cannot keep up with the adaptation of these microorganisms, as it takes years to develop a new drug (Estrela, 2018; Rodrigues et al., 2018).

Although bacterial resistance is a natural event of evolutionary adaptation, the inappropriate use of drugs in hospital, domestic and livestock environments, especially in the production of beef animals such as chickens, significantly contributes to this process occurring in an accelerated way (Furtado et al., 2019; Rodrigues et al., 2018). In view of this scenario, the present work was based on the isolation, identification and evaluation of the antimicrobial potential of microorganisms obtained from the soil of areas intended for the rearing of chickens (Gallus gallus domesticus) in the city of Igarapé-Açu, a municipality in the interior of the state of Pará, Brazil.

\section{MATERIALS AND METHODS}

The material was collected from the soil of an area destined to poultry farming located in Igarapé-açu, inland of the State of Pará. Three samples were taken, one surface, one $5 \mathrm{~cm}$ deep and one $10 \mathrm{~cm}$ deep, which were placed in plastic bags and properly identified and transported to the Laboratory of Applied Microbiology of the Center for Biological and Health Sciences of the State University of Pará (LabMicro CCBS/UEPA).
For the preparation of inoculums, a dilution of $1 \mathrm{~g}$ of soil to $10 \mathrm{ml}$ of saline solution was made, resulting in a concentration of $0.1 \mathrm{~g} / \mathrm{ml}$. The mixture was vigorously homogenized for 5 minutes and the supernatant of each sample was inoculated in Petri dishes containing Tryptic Soy Ágar (TSA) and Sabouraud Ágar media and incubated at $37^{\circ} \mathrm{C}$ for 24 hours.

After that, the samples were subjected to a thermal shock (five minutes at $95^{\circ} \mathrm{C}$, followed by 15 minutes at $-10^{\circ} \mathrm{C}$ and another 5 minutes at $95^{\circ} \mathrm{C}$ ) and inoculated again only in Tryptic Soy Ágar (TSA) medium and also, were incubated in an oven at $37^{\circ} \mathrm{C}$ for 24 hours.

After growth, bacterial strains were isolated by appearance of the colony and placed in test tubes containing Tryptic Soy Agar (TSA). The procedures for characterization of the research samples were carried out using bacterial identification techniques by traditional biochemical series.

The microorganisms were isolated, evaluating colony characteristics and Gram staining and performing biochemical tests such as catalase and oxidase, hemolysis, sugar fermentation and other biochemical tests, including motility, citrate use and sucrose fermentation test and lactose, according to standard microbiological methodology.

The sensitivity test was also carried out, in which the growth inhibition potential of strains such as Klebsiella pneumoniae, Staphylococcus aureus and Escherichia coli was evaluated through the method of diffusion in plates containing Ágar Muller Hinton. Bacterial suspensions with concentrations of approximately $0.5 \mathrm{cfu} / \mathrm{mL}$ were inoculated, using sterile disposable swabs, in plates containing Mueller Hinton Ágar, which remained at room temperature for approximately 30 minutes before the procedure. Then, the isolated and characterized strains were introduced by pricking, with the use of a properly sterile platinum loop, in specific points of the already seeded plates. It was considered as a potential inhibiting power the formation of inhibition halos of bacterial growth around the bite.

\section{RESULTS}

In the soil samples from the area destined to the rearing of chickens, a significant growth was observed in all plates. Of the 6 samples collected in this soil, the formation of bacterial colonies observed were: $1(16.7 \%)$ of cotton colony, 1 (16.7\%) of mucoid colony, 1 (16.7\%) of yellow colony and $3(50 \%)$ of white colony.

From the microscopic analysis, performed from the staining of slides made with the colonies isolated by the Gram technique, considering the morphological aspects of 
the colonies found, the bacteria presented the form of isolated gram-positive bacilli or in chains.

Through the Gram stain technique, it was possible to observe the morphology and dye affinity of the isolated bacteria, the morphological characteristics found demonstrate a predominance of bacillary forms, but with a very accentuated pleomorphism.

The biochemical analysis of the samples showed great metabolic variation, the isolated bacteria were characterized according to their metabolism on carbohydrates, motility and enzyme production, the results demonstrate a complex metabolism of this group of bacteria described in table 3 .

The bacterial morphologies found showed a predominant biochemical pattern, allowing them to differentiate beyond their morphological characteristics, but also by the production of hemolysins and the enzyme catalase (Table 4).

Bacteria isolated and previously characterized as actinobacteria were evaluated for their potential to inhibit the growth of pathogenic bacteria, only one of the six strains tested showed a positive result inhibiting the in vitro growth of $K$. pneumoniae.

\section{FIGURES AND TABLES}

Table 1. Macroscopic characteristics of colonies isolated from the ground in an area destined to the rearing of chickens.

\begin{tabular}{c|c|c}
\hline $\begin{array}{c}\text { Colony } \\
\text { morphology }\end{array}$ & $\mathbf{N}$ & $\%$ \\
\hline White Cotton & 4 & 66.7 \\
\hline Yellow Mucoid & 2 & 33.4 \\
\hline Total & 6 & 100.0 \\
\hline
\end{tabular}

Source: Author's data.

Table 2. Microscopic characterization of isolated bacteria according to colony morphology.

\begin{tabular}{l|l}
\hline $\begin{array}{c}\text { Morphological } \\
\text { characteristic }\end{array}$ & Microscopic \\
\hline White cotton & Isolated bgp and chain \\
\hline Yellow mucoid & Isolated bgp and chain \\
\hline
\end{tabular}

Source: Author's data.

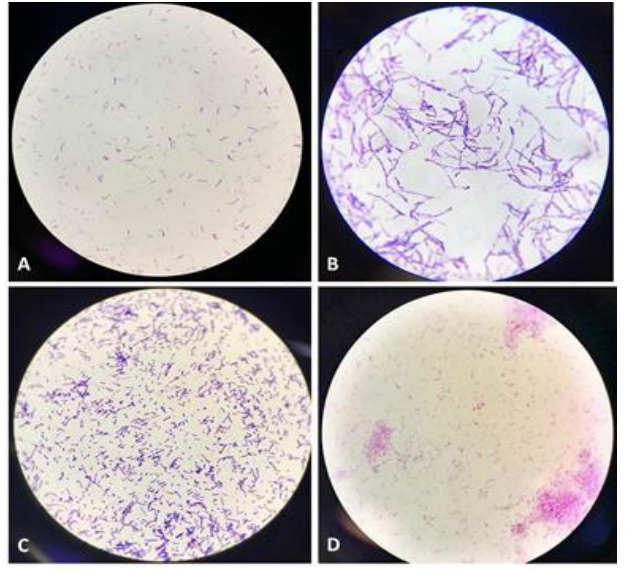

Fig.1: Microscopic characteristics ofisolated bacteria from Gram stain.

Source: Author's data.

Caption: (A) Isolated gram-positive bacilli, (B) Grampositive bacilli in chains, $(\mathrm{C})$ Gram-positive pleomorphic bacilli, (D) Gram-positive coccobacilli.

Table 3. Biochemical characterization of bacteria isolated from agricultural soil samples in Igarapé-Açú - PA.

\begin{tabular}{l|c|c|c|c}
\hline $\begin{array}{c}\text { Biochemical } \\
\text { proof }\end{array}$ & Positive & $\%$ & Negatives & $\%$ \\
\hline Lactose & 6 & 100 & - & - \\
\hline Sucrose & 3 & 50 & 3 & 50 \\
\hline Motility & 1 & 16.7 & 5 & 83.3 \\
\hline Citrate & 1 & 16.7 & 5 & 83.3 \\
\hline Hemolysis & 4 & 66.7 & two & 33.3 \\
\hline Oxidase & 4 & 66.7 & two & 33.3 \\
\hline Catalase & 4 & 66.7 & two & 33.3 \\
\hline Source: Author & & & & \\
\hline
\end{tabular}

Source: Author's data.

Table 4. Biochemical characterization according to macroscopic aspect.

\begin{tabular}{c|c|c}
\hline & Whiten Cotton & Yellow Mucoid \\
\hline TSI & AC\AC & AC\AL \\
\hline lac & + & + \\
\hline Sac & - & - \\
\hline Mot & - & - \\
\hline
\end{tabular}




\begin{tabular}{c|c|c}
\hline cit & - & - \\
\hline hem & - & + \\
\hline oxy & + & + \\
\hline cat & + & -
\end{tabular}

Source: Author's data.

Caption: TSI (Triple Sugar Iron Agar) - AC/AC: Acid base and apex; AC/AL: Acid base and alkaline apex; AL/AC: Alkaline base and acidic apex; Lac: lactose; Sac: sucrose; Mot: motility; Cit: citrate; Hem: hemolysis; Oxy: oxidase; Cat: catalase. (-): negative; (+): positive; (v): variable.

Table 5. Growth inhibition test of pathogenic bacteria involved in human pathologies

\begin{tabular}{l|c|c|c}
\hline & E. coli & $\begin{array}{c}\text { K. } \\
\text { pneumoniae }\end{array}$ & S.aureus \\
\hline White Cotton & - & + & - \\
\hline Yellow Mucoid & - & - & - \\
\hline
\end{tabular}

Source: Author's data.

\section{CONCLUSION}

Bacteria isolated from the soil of areas destined to the rearing of chickens (Gallus gallus domesticus) in the city of Igarapé-Açu, in the inland of the state of Pará, presented colonies with variable macroscopic appearance. As for the microscopic characteristics, these were indicative of grampositive bacteria suggestive of belonging to the phylum Actinobacteria. Among the isolated strains, one showed antimicrobial potential on the growth of Klebsiella pneumoniae, demonstrated by the formation of inhibition halos around the colonies. Therefore, the search for actinobacteria in unusual environments can determine the finding of new actinobacterial strains with biotechnological potential.

\section{ACKNOWLEDGEMENTS}

The authors wish to express their gratitude to the Clinical Microbiology Laboratory of the Center for Biological and Health Sciences of the Pará State University for the infrastructure and resources necessary for the development of this research.

\section{REFERENCES}

[1] Su, Y., He, Z., Yang, Y., Jia, S., Yu, M., Chen, X., \& Shen, A. (2020). Linking soil microbial community dynamics to straw-carbon distribution in soil organic carbon. Scientific reports, 10(1), 1-12.Perfect, T. J., \& Schwartz, B. L. (Eds.) (2002). Applied metacognition Retrieved from http://www.questia.com/read/107598848

[2] Srinivasiah, S., Bhavsar, J., Thapar, K., Liles, M., Schoenfeld, T., \& Wommack, K. E. (2008). Phages across the biosphere: contrasts of viruses in soil and aquatic environments. Research in microbiology, 159(5), 349357.Cognition. (2008). In Oxford reference online premium dictionary. Retrieved from http://www.oxfordreference.com

[3] Tecon, R., \& Or, D. (2017). Biophysical processes supporting the diversity of microbial life in soil. FEMS microbiology reviews, 41(5), 599623.J.ClerkMaxwell,ATreatiseonElectricityandMagnetism,3 rded.,vol.2.Oxford:Clarendon,1892,pp.68-73.

[4] Menegaço, V. M., Bassan, C. F. D., \& Losasso, P. H. L. (2017). CARACTERÍSTICAS DO HÚMUS DE MINHOCA ALIMENTADAS COM ESTERCO DE FRANGO Gallus gallus domesticus E SUSTENTABILIDADE NO MEIO RURAL. Revista Unimar Ciências, 26(1-2). K.Elissa, "Titleofpaperifknown," unpublished.

[5] de Oliveira, F. S., de Carvalho, B. F., Martins, F. B., \& Bezerra, N. V. (2021). Bioprospecção e avaliação do potencial antimicrobiano de actinobactérias do solo rizóide de açaí (Euterpe oleracea) no município de Igarapé-Açú no estado do Pará. Brazilian Journal of Development, 7(6), 64309-64318.

[6] Ramos, K., Brito, F., Nunes, K. J., Martins, C., \& Martins, S. C. (2015). Caracterização e diversidade cromogênica de actinobactérias de um nicho microbiano preservado no bioma Caatinga. Enciclopédia Biosfera, 11(21).

[7] Barka, E. A., Vatsa, P., Sanchez, L., Gaveau-Vaillant, N., Jacquard, C., Klenk, H. P., ... \& van Wezel, G. P. (2016). Taxonomy, physiology, and natural products of Actinobacteria. Microbiology and Molecular Biology Reviews, 80(1), 1-43.

[8] Medeiros, E., Cavalcante, F., Silva, V., Silveira, S. C., \& Martins, C. (2018). DIVERSIDADE CULTURAL DE CEPAS DE ACTINOBACTÉRIAS DO SEMIÁRIDO. Enciclopedia Biosfera, 15(27).

[9] Uesugi, J. H. E., Fernandes, C. F., da Silva, J. C. C., Batista, F. M., de Oliveira, F. S., de Carvalho, B. F., \& Bezerra, N. V. (2021). Bioprospecção, caracterização morfológica e bioquímica e avaliação do potencial antimicrobiano de estirpes de bactérias isolados de solos com atividade agrícola no município de Igarapé-Açu, Pará. Brazilian Journal of Development, 7(6), 59453-59460.

[10] Hopwood, D. A. (2007). Streptomyces in nature and medicine: the antibiotic makers. Oxford University Press.

[11] Brito, F., Ramos, K., Silva, R., Martins, C., \& Martins, S. C. (2015). Actinobactérias do solo rizosférico no bioma Caatinga. Enciclopédia Biosfera, 11(21).

[12] Espinosa, A. B., Guerra-Rivas, G., Ayala-Sánchez, N. E., \& Mercado, I. E. S. (2012). Antitumor activity of actinobacteria isolated in marine sediment from Todos Santos Bay, Baja California, Mexico. Revista de biología marina y oceanografía, 47(2), 317-325. 
[13] Pimentel, I. C., DIONÍSIO, J., \& SIGNOR, D. (2016). Actinobacterias. Embrapa Semiárido-Capítulo em livro científico (ALICE).

[14] Genilloud, O. (2017). Actinomycetes: still a source of novel antibiotics. Natural product reports, 34(10), 1203-1232.

[15] Quinn, G. A., Banat, A. M., Abdelhameed, A. M., \& Banat, I. M. (2020). Streptomyces from traditional medicine: Sources of new innovations in antibiotic discovery. Journal of Medical Microbiology, 69(8), 1040.

[16] da Costa, A. L. P., \& Junior, A. C. S. S. (2017). Resistência bacteriana aos antibióticos e Saúde Pública: uma breve revisão de literatura. Estação Científica (UNIFAP), 7(2), 4557.

[17] Angles, E. (2018). Uso racional de antimicrobianos y resistencia bacteriana:¿ hacia dónde vamos?. Revista Medica Herediana, 29(1), 3-4.

[18] Estrela, T. S. (2018). Resistência antimicrobiana: enfoque multilateral e resposta brasileira. Brasil, Ministério da Saúde, Assessoria de Assuntos Internacionais de Saúde. Saúde e Política Externa: os, 20, 1998-2018.

[19] Rodrigues, T. S., dos Santos, A. M. R., Lima, P. C., Moura, M. E. B., Goiano, P. D. D. O. L., \& da Silva Fontinele, D. R. (2018). Resistência bacteriana a antibióticos na Unidade de Terapia Intensiva: revisão integrativa. Revista Prevenção de Infecção e Saúde, 4.

[20] Furtado, D. M. F., Silveira, V. S. D., Carneiro, I. C. D. R. S., Furtado, D. M. F., \& Kilishek, M. P. (2019). Consumo de antimicrobianos e o impacto na resistência bacteriana em um hospital público do estado do Pará, Brasil, de 2012 a 2016. Revista Pan-Amazônica de Saúde, 10. 